\title{
Cultivation Model for Autonomous Learning Ability of Japanese Majors
}

\author{
https://doi.org/10.3991/ijet.v16i04.20481 \\ Haiyan Wei \\ Xi'an FanYi University, Xi'an, China \\ gikaien1001exafy.edu.cn
}

\begin{abstract}
As an important ability of students, autonomous learning refers to the completion of learning tasks in an independent, active, and conscious manner. Many colleges are working hard to cultivate the autonomous learning ability of their students. Taking Japanese majors as research objects, this paper carefully examines the current cultivation model for their autonomous learning ability, identifies the problems in the cultivation model, and proposes countermeasures for self-regulation and improvement from the perspectives of external environment and individuals. The results show that: autonomous learning is affected by such factors as self-efficacy, metacognition, goal setting, learning strategy, learning environment, and teachers; most college students spend 3-4h in autonomous learning daily; female students have a longer daily autonomous learning time than their male counterparts in any grade. The research results lay the basis for improving the autonomous learning ability of college students.
\end{abstract}

Keywords-Autonomous learning, language learning, Japanese major, selfefficacy, cultivation model

\section{$1 \quad$ Introduction}

As social advancement and economic development have put forward higher requirements for college students, they have to have a good autonomous learning ability to meet such requirements [1]. Autonomous learning requires certain prerequisites, such as the students must have an appropriate learning motivation, and they need to master the learning strategies that suit themselves [2]. At present, college students are numerous in number and varying greatly in individual learning status, especially the learning status of language subjects; they differ in the ability of listening, speaking, reading and writing, which has posed great challenges for the teaching in colleges and universities; in addition, there are many problems with students' learning habits, and students with a poor autonomous learning ability are often unable to complete the learning on time [3,4]. Under current conditions, cultivating college students' autonomous learning ability is an important way to overcome individual differences, improve learning efficiency, and perfect learning strategies [5]. 
All language universities in China offer Japanese language courses. The Japanese language is a minor language, and its learning is quite different from English [6]. The Chinese colleges and universities began to set up the Japanese major since 1972, right after the normalization of China-Japan diplomatic relations, the set-up time of the Japanese major in each school is relatively close, and the teaching and research of Japanese major both lagged behind the discipline settings. Japanese majors need good Japanese language skills to complete business or communication works in the future. Now, the school teaching time in colleges and universities is not enough to make students proficient in another language, and in such case, autonomous learning becomes particularly important $[7,8]$. Some scholars have proposed that autonomous learning can be divided into forethought phase, performance phase, and self-reflection phase, which are determined by the individual, environment and behavior, respectively [9]. The cultivation model of colleges and universities is an important determinant for students' autonomous learning, they need to have sufficient goals and selfefficacy, and they need schools and teachers to provide an environment for them to complete the learning tasks [10]. Taking Japanese majors as the research objects, this paper attempts to explore a cultivation model for the autonomous learning of Japanese majors, discover problems in their autonomous learning, and provide targeted countermeasures, in the hopes of providing a basis for the research on the improvement of college students' autonomous learning ability.

\section{Cultivation Model of Japanese Major in China and its Development Status}

In China, currently there are over 100 colleges, universities or vocational colleges that have opened Japanese courses, and many of them have timely adjusted their cultivation directions during constant exploration [11]. There are many Japanese-funded companies in China, and the increase in the trade and communications between China and Japan requires more Japanese professionals. More than 5,000 Japanese manufacturing companies have set up factories in China, and Japanese-funded companies are distributed in all industries [12]. Now, schools are paying more attention to the learning of Japanese majors, however, due to the limitations of curriculum setting, student learning methods, and learning time distribution, the communication ability of Japanese majors is inadequate, and they cannot fit in their positions quickly [13]. Table 1 shows the statistics of credit distribution of Japanese courses in some schools in Jiangsu province and Shandong province. In Jiangsu Province, the credit distribution of Japanese courses is: 24 credits for public platform courses, 10 credits for discipline-group sharing courses, 66 credits for professional required courses, 6.5 credits for professional elective courses, 26.5 credits for practice-week activities, 9 credits for quality-education elective courses. In Shandong Province, the credit distribution of Japanese courses is: 27.5 credits for public elective courses, 70.5 credits for professional elective courses, 39 credits for practical required courses, 42 credits for elective courses, and 3 credits for quality development. 
Japanese majors should pay attention to both the training of language ability and the learning of professional knowledge [14]. Figure 1 shows skills required for Japanese learning. The most important subject is Japanese basics, followed by Japanese speaking, Japanese listening, business Japanese, Japanese translation, Japanese reading and Japanese writing. Schools of different levels have different talent cultivation goals, "Double First-Class" schools aim to cultivate high-level research talents, while other schools target at cultivating high-quality skilled talents [15]. With the adjustment of industrial structure and the progress of economic transformation, the curriculum setting of the schools is getting closer to the actual situation of the job positions [16].

Table 1. Statistics of credit distribution of Japanese courses in some schools in Jiangsu province and Shandong province

\begin{tabular}{|c|l|}
\hline Jiangsu & $\begin{array}{c}\text { 24 credits for public platform courses; } 10 \text { credits for courses shared by professional } \\
\text { groups; } 66 \text { credits for required professional courses; } 6.5 \text { credits for professional } \\
\text { elective courses; } 26.5 \text { credits for special practice credits; Elective courses of quality } \\
\text { education for } 9 \text { credits }\end{array}$ \\
\hline Shandong & $\begin{array}{l}137 \text { credits for compulsory courses (including } 27.5 \text { credits for public compulsory courses, } \\
70.5 \text { credits for professional compulsory courses, and } 39 \text { credits for practical compulsory } \\
\text { courses); } 42 \text { credits for elective courses }(26 \text { credits for professional elective courses, } 12 \\
\text { credits for public elective courses, and } 4 \text { credits for practical training elective courses); } \\
\text { Quality development for } 3 \text { credits. }\end{array}$ \\
\hline
\end{tabular}

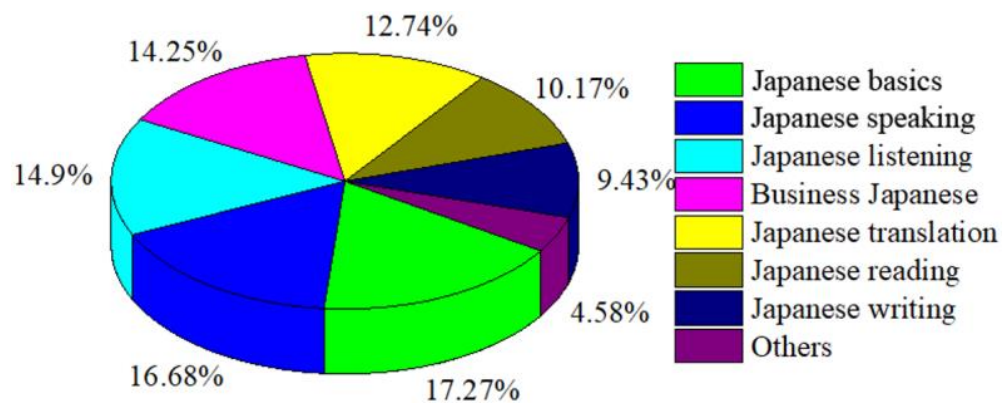

Fig. 1. Skills required for Japanese learning

\section{Influencing Factors of Autonomous Learning Ability of Japanese Majors}

\subsection{Data source and sample determination}

To determine the influencing factors of autonomous learning ability of Japanese majors, this study adopted questionnaire survey to investigate such factors. The respondents were Japanese major students from Shandong Normal University, Qufu Normal University and Qilu Normal University. Table 2 shows the information statistics of the respondents. There're 137 male respondents, accounting for $40.18 \%$, and 204 female respondents, accounting for $59.82 \%$. The proportions of student respond- 
ents from each grade are: $19.94 \%$ from the first grade, $30.50 \%$ from the second grade, $29.03 \%$ from the third grade and $20.53 \%$ from the fourth grade.

Table 2. Statistics of respondents

\begin{tabular}{|l|l|c|c|}
\hline \multicolumn{1}{|c|}{ Category } & & Number & Proportion/\% \\
\hline \multirow{3}{*}{ Gender } & Male & 137 & $40.18 \%$ \\
\cline { 2 - 4 } & Female & 204 & $59.82 \%$ \\
\hline \multirow{4}{*}{ Grade } & Grade one & 68 & $19.94 \%$ \\
\cline { 2 - 4 } & Grade two & 104 & $30.50 \%$ \\
\cline { 2 - 4 } & Grade three & 99 & $29.03 \%$ \\
\cline { 2 - 4 } & Grade four & 70 & $20.53 \%$ \\
\hline
\end{tabular}

\subsection{Determination of influencing factors}

For college students, their internal conditions are the basis of autonomous learning, and the external environment provides a support [17]. Figure 2 shows the influencing factors of autonomous learning. The factors can be divided into two types: internal factors and external factors. The internal factors include self-efficacy, metacognition, goal setting and learning strategies; and the external factors include learning environment and teachers. Self-efficacy is a manifestation of a learner's self-confidence of his/her ability in a specific activity, and it directly affects the formation of college students' autonomous learning ability. As an important cognitive variable that can affect autonomous learning, self-efficacy has an impact on one's ability and willingness for a certain task. Metacognition includes three parts: knowledge, experience, and monitor, which determines the emotional experience and cognitive experience of cognitive activities. College students can achieve controlling over their autonomous learning process by training their metacognition ability. Goal setting can stimulate college students' learning motivation, the autonomous learning of college students is closely related to goal setting. Learning strategies have a significant positive impact on the autonomous learning of college students; a good learning environment affects college students' autonomous learning positively; and teachers' various behaviors can both promote and hinder autonomous learning to varying degrees, teachers should instruct students to choose learning content that is suitable for themselves, and specify corresponding learning goals for them. Figure 3 shows the Zimmerman's autonomous learning model. From 6 psychological dimensions, the model gives 6 conditions for autonomous learning judgment, including motivation, method, time, behavior, environment and sociality. Autonomous learning emphasizes the full autonomy in learning. If a college student can achieve autonomous choice or control under these 6 conditions, it can be judged that his/her learning has achieved complete autonomous learning. Figure 4 shows the McCombs's autonomous learning model. The model divides the influencing factors of autonomous learning into three types: setting of learning goals, choice of plans and strategies, and execution and evaluation of behaviors. Factors of these three types mainly emphasize self-concept, self-image, and selfworth, while ignoring the influence of external environmental factors on autonomous learning. 


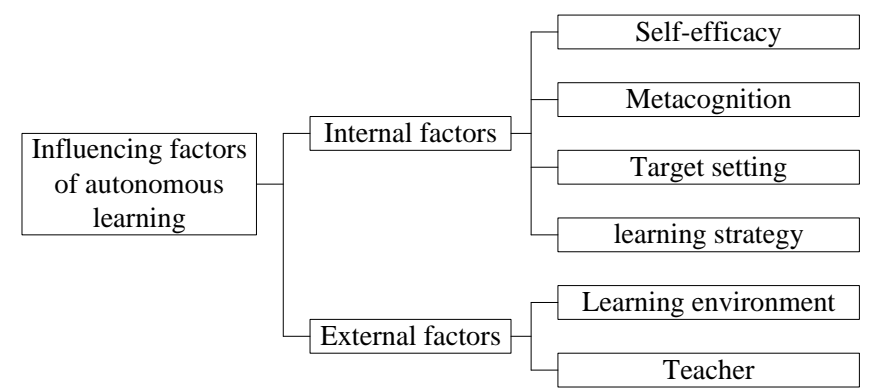

Fig. 2. Influencing factors of autonomous learning

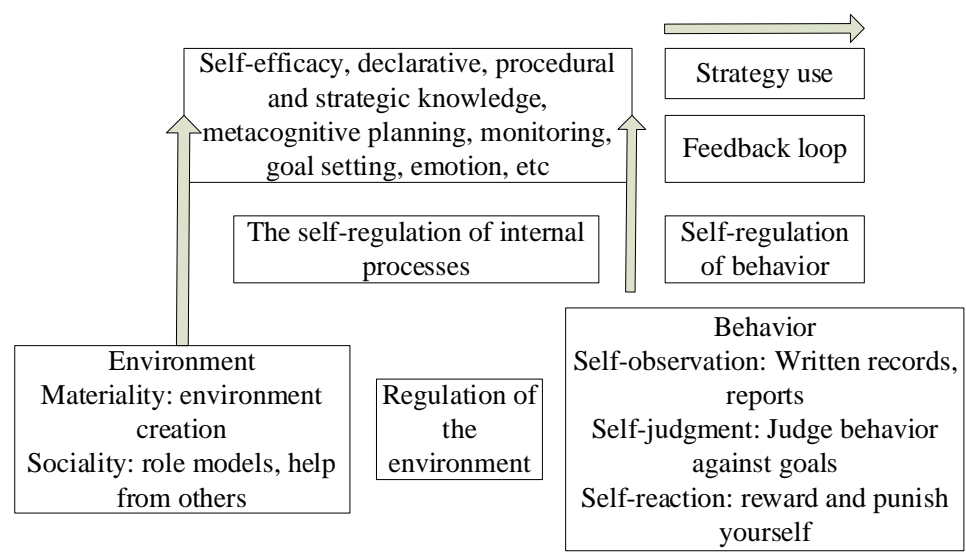

Fig. 3. Zimmerman's autonomous learning model

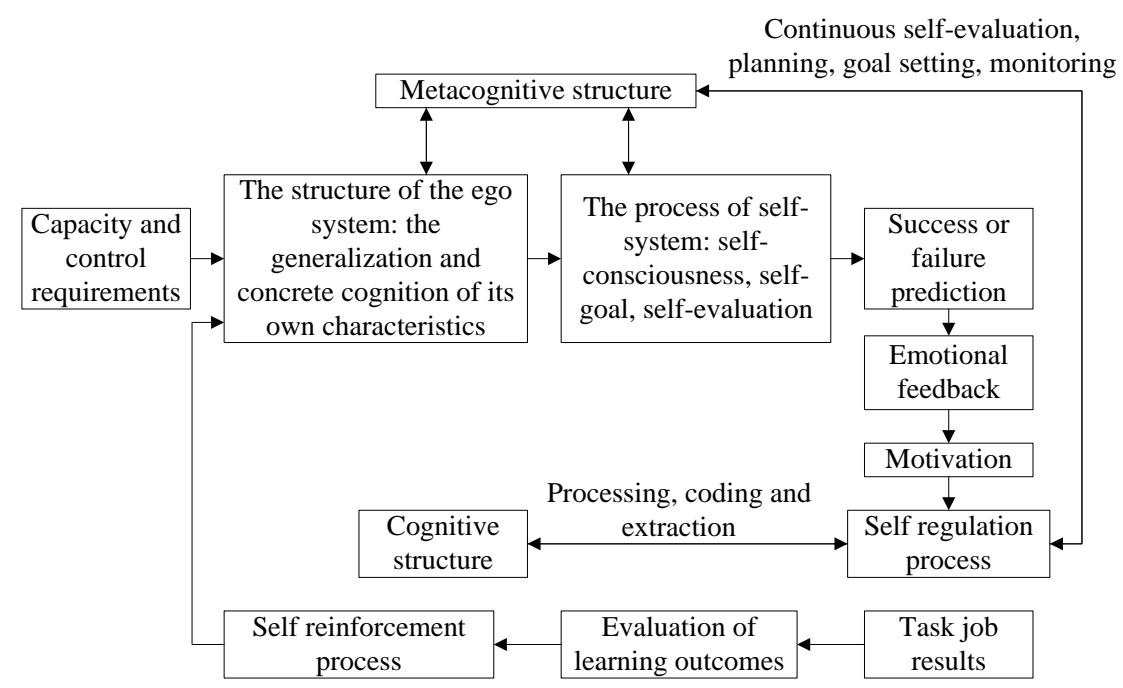

Fig. 4. McCombs's autonomous learning model 


\section{Problems in the Autonomous Learning of Japanese Majors and the Countermeasures}

\subsection{Problems in the autonomous learning of Japanese majors}

The survey results also give the autonomous learning status of Japanese majors. Figure 5 shows the average daily autonomous learning time of the respondents. It can be clearly seen that the number of respondents with an average daily autonomous learning time of 3-4 hours is the most, followed by 5-6h, 0-2h, and 7-8h, etc. Figure 6 shows the average daily autonomous learning time of male and female respondents in each grade, it can be seen that, in all grades, the average daily autonomous learning time of female respondents is more than that of male respondents, and the average daily autonomous learning time of respondents in the fourth grade is the longest. Figure 7 shows the average daily autonomous learning time of respondents in each grade. For the first-grade respondents, the proportion of students with an average daily autonomous learning time of $0-2 \mathrm{~h}$ is the most; as for the third-grade respondents, the proportion of students with an average daily autonomous learning time of 5-6h is the most; and for the fourth grade students, the proportion of students with an average daily autonomous learning time of more than $8 \mathrm{~h}$ is the most. Figure 8 shows the survey results on the satisfaction degree of respondents in autonomous learning. Most respondents are satisfied with autonomous learning, and only about $5 \%$ of the respondents are dissatisfied with it.

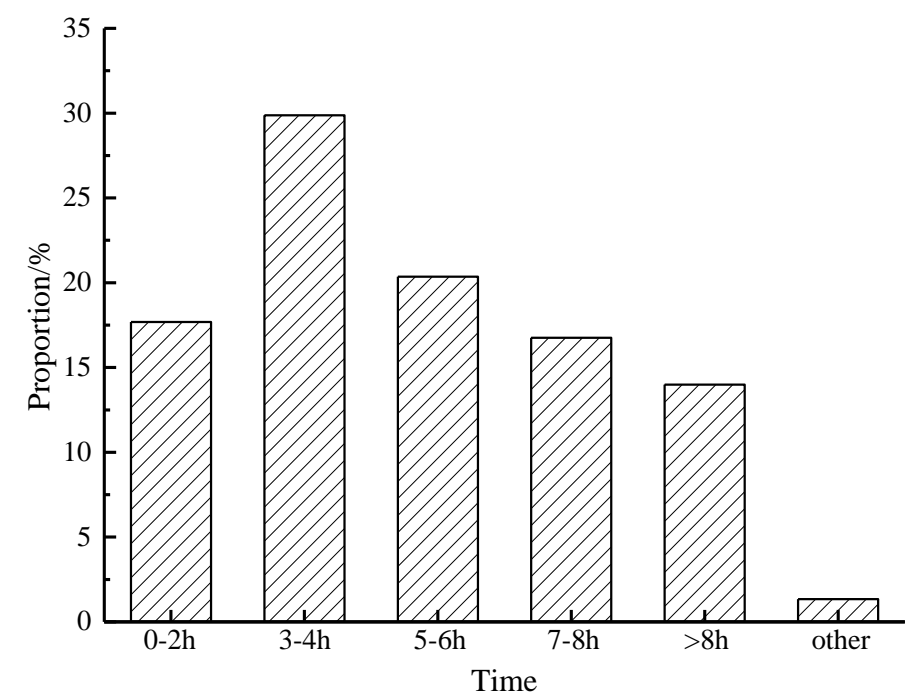

Fig. 5. Average daily autonomous learning time of respondents

The survey results show that there are many problems with the autonomous learning of Japanese majors. Their consciousness for autonomous learning is insufficient, 
unstable, irregular, externally driven, and less-motivated. Comparisons show that most students are not determined enough and they have poor self-regulation ability, weak willpower, inadequate self-control, and deficient plan execution capacity. Moreover, their learning methods are deficient; most of the students, especially freshmen and sophomores, perform autonomous learning just to complete tasks assigned by the teacher. In addition, most Japanese majors have a weak Japanese knowledge basis, and the teacher's teaching methods might not be suitable for them, which would cause many students to lose interest in language learning.

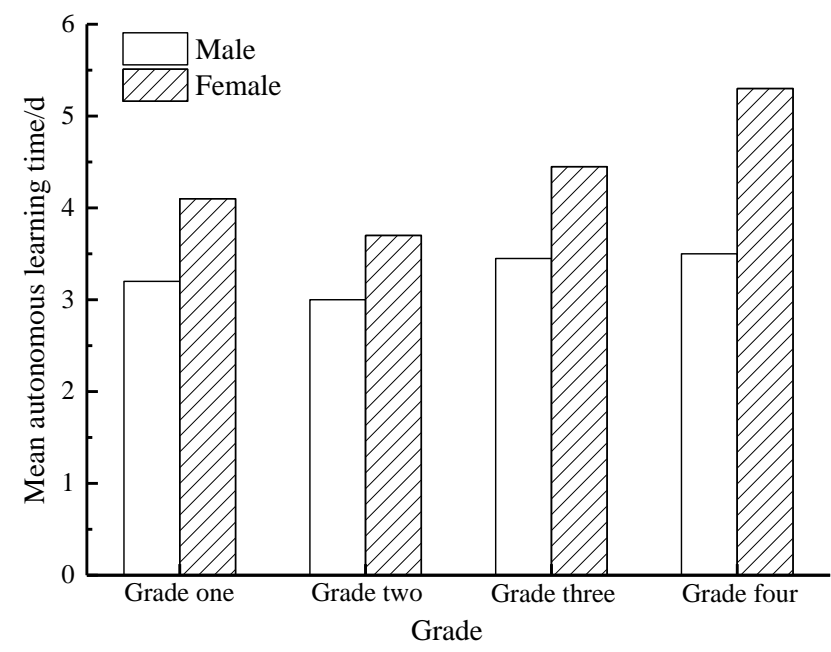

Fig. 6. Average daily autonomous learning time of male and female respondents in each grade

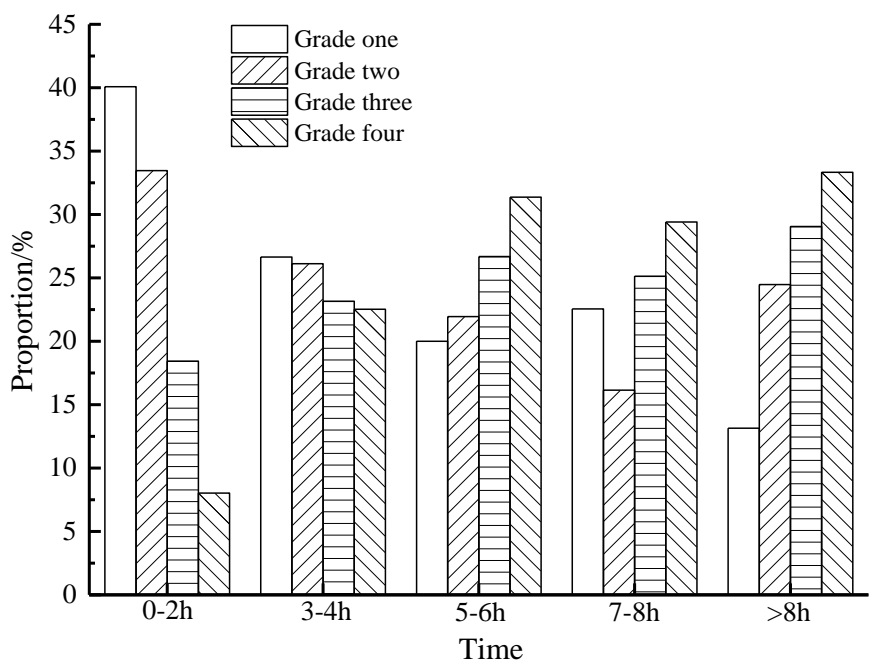

Fig. 7. Average daily autonomous learning time of respondents in each grade 


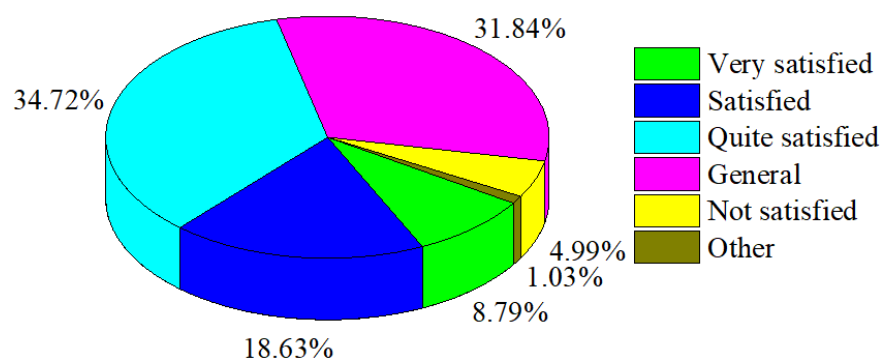

Fig. 8. Survey results on the satisfaction degree of respondents in autonomous learning

\subsection{Causes of problems in autonomous learning of Japanese majors}

For the above-mentioned problems in autonomous learning of Japanese majors, there are many reasons. Figure 9 show the causes of problems in autonomous learning summarized in this paper, including the following aspects: outdated and single-form cultivation model (shallow and plain learning content; lax assessment methods; the teaching mode is mostly lecture-based, when students have difficulties in understanding, they will gradually lose interest in learning); the style of study is unpopular, and the first-line management is weak (the learning atmosphere of students is not good; language learning stays at a low level; and the learning of Japanese knowledge is unsystematic); lack of guidance and insufficient external constraints (lack of an effective learning method; cannot effectively plan, monitor, and evaluate the learning situation); biased cognition and weak learning ability (unclear learning goals, utilitarian learning motivation, lack of interest in learning, and susceptible to environment).

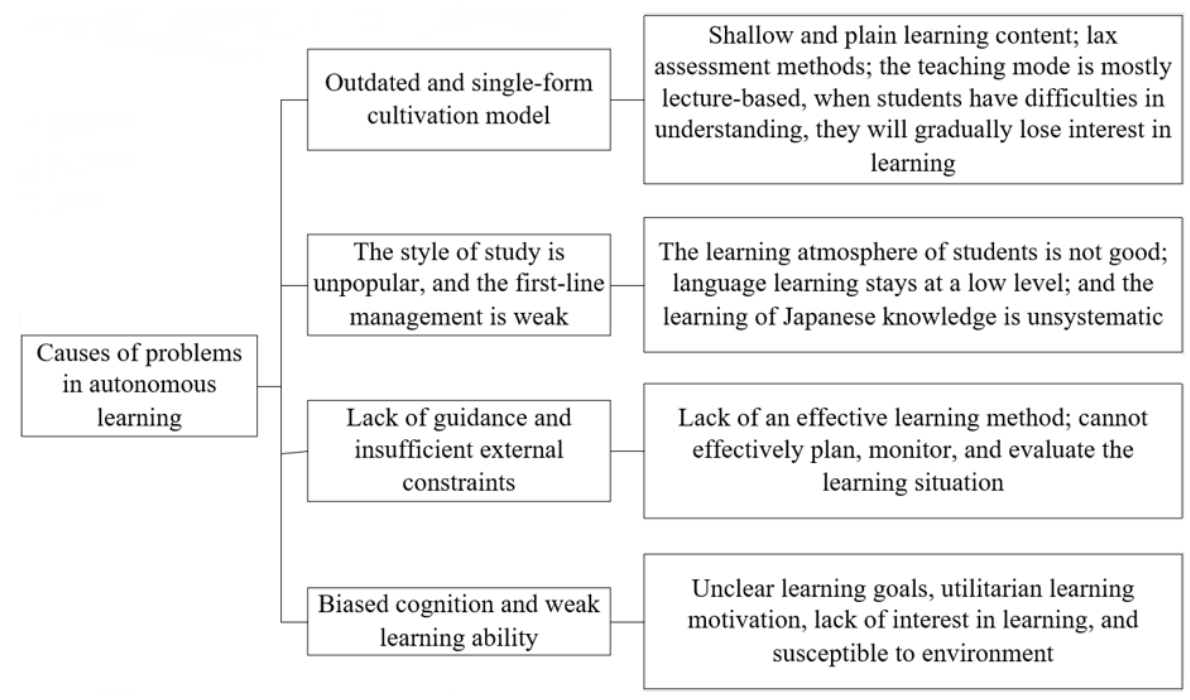

Fig. 9. Causes of problems in autonomous learning 


\subsection{Countermeasures to improve the autonomous learning ability of college students}

According to the questionnaire survey results, we found that the autonomous learning of Japanese majors is affected by environment, individual and behavior. In terms of external environment, school cultivation model, environment construction and teachers all have an impact on the autonomous learning of college students. Based on external environment and individual's self-regulation and promotion, this paper proposes the following countermeasures to improve the autonomous learning ability of college students as shown in Figure 10, including: base on objective conditions and reform cultivation model; develop a good style of study and strengthen first-line management (construct a better hardware environment in schools, cultivate good teaching style and learning style, promote communication among teachers and students); strengthen moral education and exert teachers' role as guide (reasonably allocate the faculty, clarify the training goals of Japanese majors, improve the teaching ability of teachers); set goals and improve students' learning ability (clarify learning goals, learn relevant strategies, strengthen social practice).

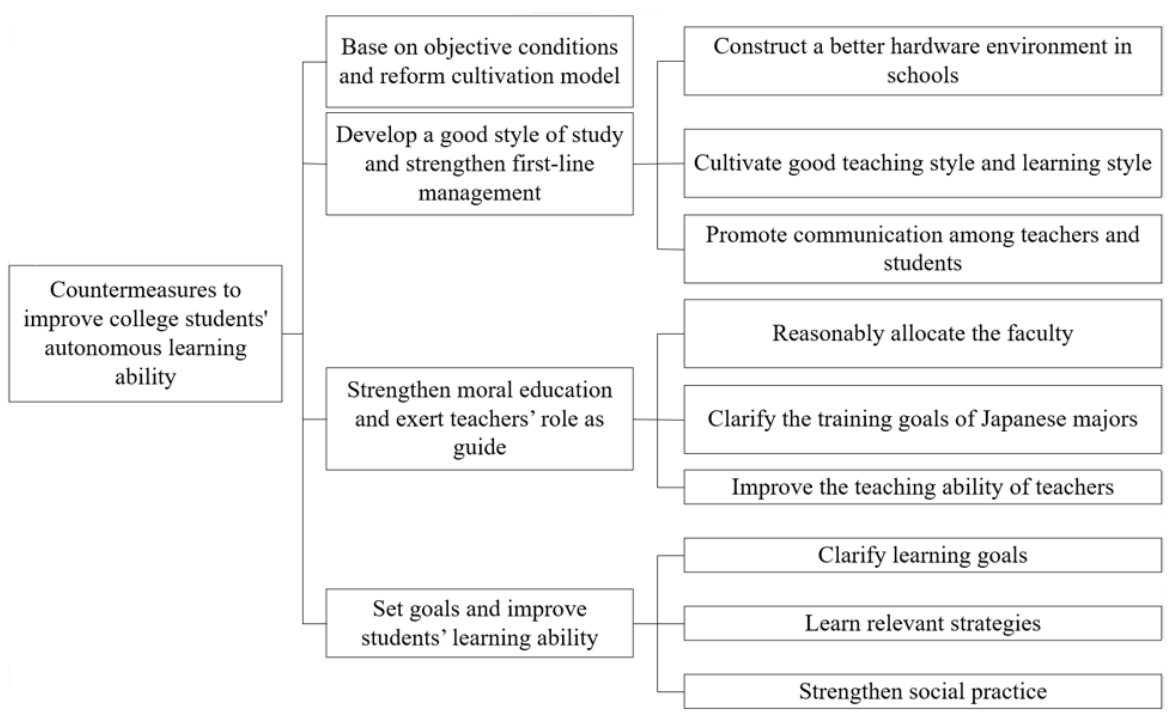

Fig. 10.Countermeasures to improve college students' autonomous learning ability

\section{Conclusion}

With Japanese majors as the research objects, this paper explored a cultivation model of autonomous learning ability, summarized problems in the autonomous learning of Japanese majors, and proposed a few countermeasures for these problems. The specific conclusions are as follows: 
1. The most important subject is Japanese basics, followed by Japanese speaking, Japanese listening, business Japanese, Japanese translation, Japanese reading and Japanese writing.

2. The influencing factors of autonomous learning can be divided into two types: internal factors and external factors. The internal factors include self-efficacy, metacognition, goal setting and learning strategies; and the external factors include learning environment and teachers.

3. Most college students spend 3-4h in autonomous learning daily; female students have a longer daily autonomous learning time than their male counterparts in any grade; the average daily autonomous learning time of students in the fourth grade is the longest.

4. The autonomous learning of Japanese majors is affected by environment, individual and behavior. To improve the autonomous learning ability of Japanese majors, we need to reform the cultivation model based on objective conditions, develop a good style of study and strengthen first-line management, strengthen moral education and exert teachers' role as guide, and set goals and improve students' learning ability.

\section{Acknowledgement}

This paper was supported by the Comparative Study on Chinese and Japanese Cultures (XFU17KYTDC06), and the First-Class Discipline Construction ProjectJapanese Major (X-YLJS201701).

\section{$7 \quad$ References}

[1] Langer, M., He, Z., Rahayu, W., Xue, Y. (2020). Distributed training of deep learning models: a taxonomic perspective. IEEE Transactions on Parallel and Distributed Systems, 31(12): 2802-2818. https://doi.org/10.1109/TPDS.2020.3003307

[2] O'Hare, C., Haughey, S., Lloyd, F., McCalmont, M., Girvin, B. (2020). An evaluation of virtual ethics discussion groups as a method of learning on a pharmacist Independent Prescribing (IP) programme. Currents in Pharmacy Teaching and Learning, 12(3): 347354. https://doi.org/10.1016/j.cptl.2019.12.015

[3] Makishima, N., Mogami, S., Takamune, N., Kitamura, D., Sumino, H., Takamichi, S., Saruwatari, H., Ono, N. (2019). Independent deeply learned matrix analysis for determined audio source separation. IEEE/ACM Transactions on Audio, Speech, and Language Processing, 27(10): 1601-1615. https://doi.org/10.1109/TASLP.2019.2925450

[4] Wang, R., Wang, Q., Yang, J., Xue, L., Hu, M. (2018). Super-resolution via supervised classification and independent dictionary training. Multimedia Tools \& Applications, 77(20): 27709-27732. https://doi.org/10.1007/s11042-018-5950-4

[5] Vekkot, S., Gupta, D. (2020). Speaker-independent expressive voice synthesis using learning-based hybrid network model. International Journal of Speech Technology, 23(3): 597-613. https://doi.org/10.1007/s10772-020-09691-1

[6] Mohammad, M.S., Muriati, M., Nurhizam, S., Yusnorizam, M.M., Shima, M. (2018). Towards a product independent ERP training model: an insight from a literature review. Australasian Journal of Information Systems, 22: 1-17. https://doi.org/10.3127/ajis.v22i0. $\underline{1537}$ 
[7] Jin, D., Li, Y. (2020). A teaching model for college learners of japanese based on online learning, International Journal of Emerging Technologies in Learning, 15(15): 162-175.

[8] Li, Y., Jin, D. (2020). A model for the influential factors of the autonomous learning ability of Japanese majors, International Journal of Emerging Technologies in Learning, 15(12): 153-167.

[9] Bracconi, M., Maestri, M. (2020). Training set design for machine learning techniques applied to the approximation of computationally intensive first-principles kinetic models. Chemical Engineering Journal, 400: 125469. https://doi.org/10.1016/j.cej.2020.125469

[10] Al Machot, F., Elmachot, A., Ali, M., Al Machot, E., Kyamakya, K. (2019). A deeplearning model for subject-independent human emotion recognition using electrodermal activity sensors. Sensors, 19(7): 1659. https://doi.org/10.3390/s19071659

[11] Kiwanuka, J., Miiro, R.F., Matsiko, F.B., Nkalubo, S. (2020). Using the learning transfer system inventory to test the effects of trainee and training design characteristics on the transfer of agricultural training in Uganda. International Journal of Training and Development, 24(4): 374-383. https://doi.org/10.1111/ijtd.12202

[12] Shareef, Z., Mohammadi, P., Steil, J. (2016). Improving the Inverse Dynamics Model of the KUKA LWR IV+ using Independent Joint Learning. 7th IFAC Symposium on Mechatronic Systems, 49(21): 507-512. https://doi.org/10.1016/j.ifacol.2016.10.653

[13] Liu, J., Shindo, H., Matsumoto, Y. (2019). Development of a computer-assisted Japanese functional expression learning system for Chinese-speaking learners. Educational Technology Research and Development, 67(5): 1307-1331. https://doi.org/10.1007/s114 23-019-09669-0

[14] Chang, L.Y., Plaut, D.C., Perfetti, C.A. (2016). Visual complexity in orthographic learning: modeling learning across writing system variations. Sentific Studies of Reading, 20(1): 64-85. https://doi.org/10.1080/10888438.2015.1104688

[15] Shinohara, Y., Takahashi, N., Lee, Y., Ohmura, T., Kinoshita, T. (2019). Development of a deep learning model to identify hyperdense MCA sign in patients with acute ischemic stroke. Japanese Journal of Radiology, 38(2): 112-117. https://doi.org/10.1007/s11604019-00894-4

[16] Fryer, L., Ginns, P., Walker, R. (2016). Reciprocal modelling of Japanese university students' regulation strategies and motivational deficits for studying. Learning \& Individual Differences, 51: 220-228. https://doi.org/10.1016/j.lindif.2016.08.032

[17] Tateishi, K., Matsubayashi, T., Yoshimoto, K., Sakemi, T. (2013). An investigation of the basic education of Japanese nurses: comparison of competency with European nurses. Nurse education today, 33(5): 552-557. https://doi.org/10.1016/j.nedt.2012.08.008

\section{Author}

Haiyan Wei, female, she graduated from Xi'an International Studies University, with master degree in Japanese Language and Literature. Now, she is an associate professor working Xi'an FANYI University, mainly engaging in Japanese education and research. Apart from normal education task, her focus also invests in the research on Japanese literature and its relevant translations. She has contributed for translations of 5 Japanese works, including Snow Day (Nagai Kafuu), Tomb of Cat (Natsume Soseki), Story of the Mountain and the Moon (Nakajima Atsushi), Legend of Emperor Yang and the like (Miyazaki Itisada). Moreover, she has published more than 20 theses, participated in and held 6 municipal level and 10 school level scientific researches till now.

Article submitted 2020-12-10. Resubmitted 2021-01-07. Final acceptance 2021-01-09. Final version published as submitted by the authors. 